
in association to mineral fertilizer. Horticultura Brasileira 39: 444-450. DOI: http://dx.doi.org/10.1590/s0102-0536-20210414

\title{
Productivity of lettuce in greenhouse as affected by humic and fulvic acids application in association to mineral fertilizer
}

\author{
Ana Cristina Lüdtke ${ }^{1} \mathbb{D}$; Deborah P Dick ${ }^{1,2} \mathbb{D}$; Luiza Morosino ${ }^{2} \mathbb{D}$; Vicente Kraemer ${ }^{2} \mathbb{D}$ \\ ${ }^{1}$ Universidade Federal do Rio Grande do Sul, Depto. de Solos (UFRGS), Porto Alegre-RS, Brasil; krisludtke@yahoo.com.br (author for \\ correspondence); deborah.dick@ufrgs.br; ${ }^{2}$ Universidade Federal do Rio Grande do Sul, Instituto de química (UFRGS), Porto Alegre-RS, \\ Brasil; lu_morosino@hotmail.com; vicente_kraemer@hotmail.com
}

\begin{abstract}
Humic substances (HS) have proved to be effective in improving the productivity of vegetable crops. We examined the effect of commercial biostimulants rich in humic (HA) and fulvic acids (FA) obtained from leonardite on agronomic efficiency and nutrient content in the leaves of lettuce (Lactuca sativa). A greenhouse experiment was carried out employing 2.5-L pots containing Ultisol samples that were supplied with commercial biostimulants rich in HA and FA, alone and in combination with NPK mineral fertilizer. The application of HS biostimulants associated to mineral fertilization to the lettuce plants provided the greatest values of the studied variables, namely: plant height and diameter, leaf number per plant and root length. The combination of FA biostimulants and mineral fertilization increased the lettuce productivity relative to the inorganic fertilizer alone. The combined application of rich biostimulants FA and HA with NPK fertilizes influenced $\mathrm{K}$ and Fe uptake by the plants, and their accumulation in the aerial portion. Our results suggest that HS products potentialize the nutritional effect of the mineral fertilizer, when applied in combination.
\end{abstract}

Keywords: Lactuca sativa, humic acids, fulvic acids, biostimulant.

\section{RESUMO}

Produtividade da alface em resposta à aplicação de ácidos fúlvicos e ácidos húmicos associado a fertilizante mineral em casa de vegetação

As substâncias húmicas ( $\mathrm{SH})$ têm se mostrado eficazes em incrementar a produtividade de hortaliças. O objetivo deste trabalho foi avaliar o efeito de bioestimulantes comerciais ricos em ácidos húmicos $(\mathrm{AH})$ e fúlvicos (AF), obtidos de leonardita, na eficiência agronômica da cultura de alface e teor de nutrientes na planta. Foi realizado um experimento em casa-de-vegetação em vasos de $2,5 \mathrm{~L}$ com amostras de Argissolo, aos quais foram aplicados bioestimulantes comerciais ricos em $\mathrm{AH}$ e em $\mathrm{AF}$, isoladamente e em combinação com o fertilizante mineral NPK. A aplicação dos bioestimulantes à base de SH associada à fertilização mineral na cultura da alface apresentou os maiores valores das variáveis estudadas: altura e diâmetro de plantas, número de folhas por planta e comprimento de raiz. A combinação do bioestimulante rico em AF e o fertilizante mineral aumentou a produção da alface em relação à aplicação isolada do fertilizante inorgânico. A aplicação combinada dos bioestimulantes ricos em AF e em AH com o fertilizante NPK influenciou a absorção de K e Fe pelas plantas, e seu acúmulo na parte aérea. Nossos resultados sugerem que as $\mathrm{SH}$ potencializam o efeito nutricional do fertilizante mineral, quando aplicadas conjuntamente.

Palavras-chave: Lactuca sativa, ácidos húmicos, ácidos fúlvicos, bioestimulantes.

\section{Received on January 5, 2021; accepted on August 10, 2021}

$\mathrm{V}$ egetable crops in Brazil span a land area of around 800 thousand ha and with an overall of 17.9 million tons produce. One of the most prominent vegetables cultivated in Brazil is lettuce (Lactuca sativa), one of the main consumed leafy and most intensively produced crops, with approximately 1.50 million tons each year (Brazilian Horti \& Fruti Yearbook, 2019). On a global scale, 26.9 million tons of lettuce were produced in the world in 2017 (FAO, 2017).

The use of mineral fertilizers in the cultivation of lettuce is a common agricultural practice yielding satisfactory results for productivity. Leafy vegetables have a short cycle and therefore substrates rich in organic matter and with high and immediate nutrient availability are required. Thus, mineral fertilizer applications at high rates are common in lettuce cultivation (Zandonadi et al., 2014). However, the cost of mineral fertilizers and environmental pollution arising from their frequent application compromise environmental sustainability.
In recent years, new strategies and technologies have been studied in order to improve the sustainability of agricultural ecosystems such as the application of HS-based products, also called HS-biostimulants (García et al., 2018; Nardi et al., 2021), which can prevent and/or reduce the negative effects caused by excessive and continuous use of mineral fertilizer (Turan et al., 2021).

In this context, the use of HS-based biostimulants has been proposed as an alternative for viable and to increment 
vegetable production (Calvo et al., 2014; Nardi et al., 2021). Furthermore, the foliar application of HS-based biostimulants associated or not with mineral fertilizers has been investigated as an alternative to reduce the use of mineral fertilizers (Canellas et al., 2015; Turan et al., 2021).

Biostimulants are defined as any substance or microorganism that, when applied to plants, enhances nutrition efficiency, improves abiotic stress tolerance and/or crop productivity and quality, regardless of its nutrients content (Jardin, 2015). It is estimated that the world market of the biostimulants will grow by $10.4 \%$ in 2021 , reaching an application area of 24.9 million hectares (with an increase of $11.7 \%$ on average per year) (Wu, 2018). One of the main advantages of the use of biostimulants is that little amounts of the product are required in order to promote relevant changes in the physiological plant system and therefore reducing the production costs (Jesus et al., 2016; Nardi et al., 2021). HS extracted and isolated from different sources of organic matter are known to affect the physiological mechanisms of plants by boosting root and aerial growth and increasing nutrient uptake (Canellas et al., 2015; Nardi et al., 2021). Therefore, HS-based products are considered biostimulants (Zandonadi et al., 2014; Canellas et al., 2015) and may provide a friendly economic and environmental alternative to mineral fertilizers.

The supramolecular model for HS assumes that humic molecules bind to one another through weak interactions and hydrophobic bonds that can be easily broken by organic acids in the rhizosphere, thereby releasing bioactive substances and boosting plant development as a result (Zandonadi et al., 2014; Piccolo, 2016). These bioactive substances behave similarly to auxins and can thus induce some physiological responses in plants (Canellas et al., 2015; Nardi et al., 2021).

HS contribute to crop quality and productivity by facilitating nutrient uptake by roots, which boosts root growth and allows roots to explore greater soil volumes (Nardi et al.,
2021). Moreover, the application of HS may reduce the application of mineral fertilizers due to their potential to form complexes and chelates (Calvo et al., 2014), enhancing the increase in nutrient absorption by plants (Canellas et al., 2015). Kasemi (2013) assessed the vegetative and reproductive growth after applying a solution of HA and potassium (K) jointly on cucumber leaves and verified that the composed fertilizer increased plant growth and number of leaves, as well as plant reproduction and yield (dry mass). The effect of soaking seeds with HS was examined by Baldotto et al. (2017) on maize (Zea mays), and an increase of the initial plant growth (viz., root and aerial biomass) was observed. The authors ascribed this effect to the biostimulant action of auxins from HS.

Regarding nutrients absorption, previous studies reported increased $\mathrm{K}$ content in potato tubers when HS were applied to the soil. Furthermore, leaf application of HA solution increased $\mathrm{K}, \mathrm{Mn}$ and $\mathrm{Zn}$ contents in the plant, thus suggesting that HA enhanced the absorption of the three elements (Suh et al., 2014a). Also, foliar application of HA in combination with a mineral fertilizer to garlic (Allium sativum) increased $\mathrm{K}, \mathrm{Mn}$ and $\mathrm{Fe}$ contents of the plants (Denre et al., 2014).

The effects of HS on plant growth have largely been studied by applying nutrient solutions or liquid HS to plant leaves (Kasemi, 2013; Denre et al., 2014; Canellas et al., 2015; Nardi et al., 2021). Despite the good results obtained from the use of HS-based biostimulants, the effectiveness of commercial biostimulants on vegetables depends on several factors such as the plant species, the composition of the product used, form of application (sprayed especially direct on the leaves), among others (Nardi et al., 2021). This variability of effects can prevent generalization, so it becomes necessary to investigate the effect of HS-biostimulants not only sprayed on plants but also applied directly to the soil.

In this work, we examined the influence of HS-based biostimulants alone and in combination with a mineral fertilizer, applied directly to soil, on the productivity and nutrient content in the leaves of lettuce cultivated in greenhouse.

\section{MATERIAL AND METHODS}

A pot experiment was conducted in greenhouse (from September to November) located at the Faculty of Agronomy, Department of Soil Science of the Federal University of Rio Grande do Sul (UFRGS), Brazil (3004'26"S, $\left.51^{\circ} 08^{\prime} 07^{\prime \prime} \mathrm{W}\right)$.

The used soil was an Ultisol (Soil Survey Staff), collected at the $0-10 \mathrm{~cm}$ depth from an agriculture area cultivated with oat and ryegrass, limed two years before. The main soil characteristics are: organic $\mathrm{C}$ content $=16.4 \mathrm{~g} \mathrm{~kg}^{-1}, \mathrm{pH}_{\mathrm{H} 2 \mathrm{O}}$ $($ in water $)=5.6, \mathrm{P}($ Mehlich $)=8.4 \mathrm{mg}$ $\mathrm{dm}^{-3}$; exchangeable cations: $\mathrm{K}=110$ $\mathrm{mg} \mathrm{dm}{ }^{-3}, \mathrm{Ca}=7.2 \mathrm{cmol}_{\mathrm{c}} \mathrm{kg}^{-1}, \mathrm{Mg}=3.1$ $\mathrm{cmol}_{\mathrm{c}} \mathrm{kg}^{-1}, \mathrm{Al}=0.0 \mathrm{cmol}_{\mathrm{c}} \mathrm{kg}^{-1}$, potential acidity $(\mathrm{H}+\mathrm{Al})=6.9 \mathrm{cmol}_{\mathrm{c}} \mathrm{kg}^{-1}$, texture: $350 \mathrm{~g} \mathrm{~kg}^{-1}$ sand; $530 \mathrm{~g} \mathrm{~kg}^{-1}$ silt and 210 $\mathrm{g} \mathrm{kg}^{-1}$ clay.

The experimental design was completely randomized and involved six different treatments with four replications each. Two different HSbased commercial biostimulants, obtained from leonardite, were used, namely: Growmate Plant ${ }^{\mathrm{TM}}$, rich in FA $(1.35 \% \mathrm{~m} / \mathrm{m})$ and Growmate Soil ${ }^{\mathrm{TM}}$, rich in HA $(1.44 \% \mathrm{~m} / \mathrm{m})$ (Growmate, 2020). The solution density of both products was $1.09 \mathrm{~g} / \mathrm{cm}^{3}$. From now on, for discussion purposes, the product Growmate Plant ${ }^{\mathrm{TM}}$ will be referred as FA and Growmate Soil ${ }^{\mathrm{TM}}$ as HA. The chemical properties of the two HS-based biostimulants are summarized in Table 1 and were taken from the label of the products. The employed treatments were Control (no fertilizer), HA, HA+NPK, NPK, FA and FA+NPK, where NPK represents the mineral fertilizer.

Each 2.5-L pot was filled with $2 \mathrm{~kg}$ soil before transplantation of a seedling of lettuce (cultivar Veronica) containing four leaves. For the treatments with NPK addition, the mineral fertilizer was incorporated into the soil mass at the recommended rate for lettuce crops (CQFS-RS/SC, 2016), namely: 100 $\mathrm{kg} \mathrm{N} \mathrm{ha}{ }^{-1}$ as urea distributed in four 
applications; plus $100 \mathrm{~kg} \mathrm{P}_{2} \mathrm{O}_{5} \mathrm{ha}^{-1}$ and $160 \mathrm{~kg} \mathrm{~K}_{2} \mathrm{O} \mathrm{ha}^{-1}$, both being added to soil in the pots two days prior to planting. For the treatments that included HSbased biostimulants, the products were applied at the recommended rate of $4 \mathrm{~L} \mathrm{ha}^{-1}$. For this purpose, $20 \mathrm{~mL}$ of either FA or HA commercial solution were diluted in $1 \mathrm{~L}$ distilled water, and each pot received $5 \mathrm{~mL}$ of solution one day after NPK addition (if that was the case). A single dose of HA- or FAbased biostimulant was applied using a graduated pipette, in a small cavity of the soil surface of around $5 \mathrm{~mm}$ depth. One day after incorporation of HS-based biostimulants into the soil, the seedlings were transplanted.

The plants were monitored on a weekly basis for number of leaves (NL), height and diameter. Plant height was measured between the bottom of the plant lap and the highest leaf top with a centimeter-graduated ruler. Plant diameter was also measured with a ruler. Soil moisture content was adjusted to $80 \%$ field capacity (determined previously according to Tedesco et al., 1995) and kept constant by monitoring pot weight daily and adding water if needed. In this way, no lixiviation neither hydric stress occurred. Weeds were managed manually whenever necessary.

Four plants per treatments were harvested at 21, 35 and 48 days after transplant date (DAT) of seedlings for separation of their root and aerial portions. Roots were extracted from the pots, carefully stripped of soil, washed and dried on paper to measure their length (RL). Then, plants were weighed on a $0.001 \mathrm{~g}$ precision analytical balance (Digimed, DG-500) to determine aerial and root fresh mass (AFM and RFM, respectively). The two plant fractions were conditioned in paper bags for drying until constant weight in a stove at $65^{\circ} \mathrm{C}$ for 72 hours. Aerial and root dry mass (ADM and RDM) respectively, were determined gravimetrically, and thereafter the plant material was ground using a Willey type mill and passed through a 40-mesh sieve. After homogeneization, ADM and RDM materials were packed in bags, properly labelled and stored in a dry chamber until analysis.

Contents of macro- and micronutrients of ADM were determined at 48 DAT, by ICP-OES (Perkin Elmer $8300 \mathrm{Dv})$ in the extracts of nitroperchloric acid digestion (Tedesco et al., 1995). Nutrient accumulation in shoots was calculated based on dry mass and the nutrient contents.

The experimental results were submitted to analysis of variance (ANOVA) and the means compared via Tukey's test at 5\% significance level. The statistical software Sisvar (Ferreira, 2011) was used to analyze the data.

\section{RESULTS AND DISCUSSION}

Regarding plant related variables (Table 2), all tested treatments presented greater values than those shown by control at 48 DAT, except HA treatment for plant height (Table 2). For both number of leaves and plant diameter the values decreased in the order: $\mathrm{FA}+\mathrm{NPK}$ $>\mathrm{NPK}=\mathrm{HA}+\mathrm{NPK}=\mathrm{HA}=\mathrm{FA}>$ Control. For plant height the effect decreased in the order $\mathrm{FA}+\mathrm{NPK}>\mathrm{NPK}=\mathrm{HA}+\mathrm{NPK}$ $=\mathrm{FA}>\mathrm{HA}=$ Control, whereas for root length the observed order was HA+NPK $\geq \mathrm{FA}+\mathrm{NPK}=\mathrm{HA} \geq \mathrm{NPK}=\mathrm{FA}>$ Control (Table 2). Our results clearly show that HS-based biostimulants, when applied isolated, exerted similar effect as the mineral fertilizer. Even though in the present study the mechanism of these effects was not investigated, literature reports that HS stimulate the $\mathrm{H}+-$ ATPase activity in the plasma membrane, a typical effect of auxins, and thus promote nutrient intake (Canellas et al., 2015).

Overall, FA+NPK treatment provided the greatest values for plant attributes at 48 DAT. These values differed from those of the Control treatment from the 14 DAT for NF, 21 DAT for plant height and diameter, and 35 DAT for RL (Table 2). The greater effect of FA+NPK treatment on the lettuce productivity may be assigned to the stimulation of secondary roots growth by FA as verified by Canellas et al. (2015), which in turn may have enhanced the absorption of the nutrients supplied by the NPK fertilizer. Similar behavior was observed with maize plants after the combined application of FA and NPK (Sootahar et al., 2019).

Interestingly, the $\mathrm{HA}+\mathrm{NPK}$ treatment did not differ from the NPK, $\mathrm{HA}$ and FA treatments regarding NL, plant height or plant diameter, but presented the greatest root length at 48 DAT. Possibly the effect of HA in the absorption of nutrients, as reported by other authors (Canellas et al., 2015; Turan et al., 2021) may also have enhanced the absorption of nutrients from NPK. But, in opposite to the FA in the FA+NPK treatment, it did not promote their translocation within the plant (Nardi et al., 2021).

According to the standards of the Brazilian program for horticulture standardization (Hortibrasil, 2019), the plants harvested in our experiment at the end of the lettuce cycle are within the commercial standards for this vegetable, regardless of the type of fertilizer used.

The HA+NPK, FA+NPK and NPK treatments led to an increase of aerial fresh mass (AFM) at 21 DAT relative

Table 1. Chemical characteristics of the two HS-based biostimulants ${ }^{1}$. Porto Alegre, UFRGS, 2013.

\begin{tabular}{|c|c|c|c|c|c|c|c|c|c|c|c|}
\hline \multirow{2}{*}{ Biostimulants } & $\mathrm{OC}^{2}$ & $\mathbf{P}$ & $\mathbf{N}_{\text {total }}$ & $\mathbf{K}$ & $\mathbf{C a}$ & Mg & $\mathrm{Cu}$ & Mn & $\mathbf{F e}$ & $\mathbf{Z n}$ & \multirow{2}{*}{ pH } \\
\hline & \multicolumn{4}{|c|}{$\left(\mathrm{g} \mathrm{kg}^{-1}\right)$} & \multicolumn{6}{|c|}{$\left(\mathrm{mg} \mathrm{kg}^{-1}\right)$} & \\
\hline Growmate Plant ${ }^{\mathrm{TM} 3}$ & 310 & 52.1 & 9.7 & 1.3 & 0.3 & 6.4 & 0.01 & 0.01 & 24.64 & 23.8 & 6.6 \\
\hline Growmate Soil ${ }^{\mathrm{TM} 3}$ & 398 & 54.5 & 9.7 & 5.9 & 0.3 & 7.1 & 0.01 & 0.01 & 47.38 & 27.0 & 6.6 \\
\hline
\end{tabular}

${ }^{1}$ Information given by the biostimulants producer: Growmate $(2020) ;{ }^{2} \mathrm{OC}=$ organic carbon. 
to the other three treatments (Figure 1a). However, the ADM value obtained with the FA+NPK treatment was not significantly different from the one used as Control treatment at 21 DAT (Figure 1b). The higher accumulation of water observed under the FA+NPK treatment is probably associated with FA acting in the plant metabolism, inducing the reduction of stomata opening and transpiration, thus reducing water loss (Geng et al., 2020). The NPK and HA+NPK treatments exhibited the greatest aerial dry mass (ADM) as a result of promoting water and nutrient uptake. Previously, Baldotto \& Baldotto (2016) found out that maize (Zea mays) responded favorable to HA when applied to seeds prior to planting as an increase of $41 \%$ dry matter relative to their Control treatment (no HA added) was observed.

Neither AFM nor ADM differed among treatments or from the Control values at 35 DAT (Figures 1a and 1b). Also, AFM at the end of the experiment (48 DAT), decreased in the following sequence: $\mathrm{FA}+\mathrm{NPK} \approx$ $\mathrm{NPK}>\mathrm{HA}+\mathrm{NK} \approx \mathrm{HA} \approx \mathrm{FA}>$ Control. However, the greatest productivity in terms of ADM was obtained with the combined treatments (HA+NPK and FA+NPK), followed by NPK and HA (Figure 2b). This result reinforces the effect of the two HS biostimulants (HA and FA) when applied jointly with the inorganic fertilizer (NPK). Stimulating effects of foliar application of FA and HA on ADM of tomato (Lycopersicon esculentum) and lettuce (Lactuca sativa) crops have been reported early (Suh et al., 2014b; Rodrigues et al., 2018).

None of the HS biostimulants influenced RFM or RDM at 21 DAT (Figures 1c and 1d). However, the two combined treatments (HA+NPK and $\mathrm{FA}+\mathrm{NPK}$ ) provided the greatest
RFM and RDM at 35 and 48 DAT. The isolated effect of HS on root mass has been recorded previously in pineapples (Baldotto et al., 2010) and maize (Baldotto \& Baldotto, 2016).

Concerning the analysed macro

Table 2. Number of leaves (NL), plant diameter, plant height and root length (RL) of the six treatments during the lettuce growth cycle. Porto Alegre, UFRGS, 2013.

\begin{tabular}{|c|c|c|c|c|c|c|}
\hline Days & Control & HA & HA+NPK & NPK & FA & FA+NPK \\
\hline \multicolumn{7}{|c|}{ Number of leaves } \\
\hline 0 & $4^{\mathrm{ns}}$ & $4^{\mathrm{ns}}$ & $4^{\mathrm{ns}}$ & $4^{\mathrm{ns}}$ & $4^{\mathrm{ns}}$ & $4^{\mathrm{ns}}$ \\
\hline 21 & $8.5^{\mathrm{ab}}$ & $9^{a b}$ & $10.2^{\mathrm{ab}}$ & $9.75^{\mathrm{ab}}$ & $9^{a b}$ & $10.7^{\mathrm{a}}$ \\
\hline 35 & $15.7^{\mathrm{bc}}$ & $13.2^{\mathrm{c}}$ & $15.7^{\mathrm{bc}}$ & $18.5^{\mathrm{ab}}$ & $12.7^{\mathrm{c}}$ & $22.2^{\mathrm{a}}$ \\
\hline \multirow[t]{2}{*}{48} & $18.2^{\mathrm{c}}$ & $20.7^{\mathrm{bc}}$ & $22.2^{\mathrm{b}}$ & $24^{\mathrm{ab}}$ & $22.5^{\mathrm{b}}$ & $27.5^{\mathrm{a}}$ \\
\hline & \multicolumn{6}{|c|}{ Diameter (cm) } \\
\hline 0 & $5^{\mathrm{ns}}$ & $5^{\mathrm{ns}}$ & $5^{\mathrm{ns}}$ & $5^{\text {ns }}$ & $5^{\mathrm{ns}}$ & $5^{\mathrm{ns}}$ \\
\hline 21 & $16.3^{\mathrm{b}}$ & $15.1^{b}$ & $16.1^{\mathrm{b}}$ & $23.5^{\mathrm{a}}$ & $14.8^{\mathrm{b}}$ & $24.1^{\mathrm{a}}$ \\
\hline 35 & $20.5^{\mathrm{c}}$ & $27.1^{\mathrm{b}}$ & $25.5^{\mathrm{b}}$ & $26.1^{\mathrm{b}}$ & $23.8^{\mathrm{bc}}$ & $33.3^{\mathrm{a}}$ \\
\hline \multirow[t]{2}{*}{48} & $24.7^{\mathrm{c}}$ & $30.5^{\mathrm{b}}$ & $29.2^{\mathrm{b}}$ & $28.7^{\mathrm{b}}$ & $29.7^{\mathrm{b}}$ & $34.7^{\mathrm{a}}$ \\
\hline & \multicolumn{6}{|c|}{ Plant height (cm) } \\
\hline 0 & $5^{\mathrm{ns}}$ & $5^{\mathrm{ns}}$ & $5^{\mathrm{ns}}$ & $5^{\mathrm{ns}}$ & $5^{\mathrm{ns}}$ & $5^{\mathrm{ns}}$ \\
\hline 21 & $7.1^{\mathrm{b}}$ & $7.6 \mathrm{~b}$ & $11.0 \mathrm{a}$ & $9.1 \mathrm{ab}$ & $7.7 \mathrm{~b}$ & $10.7^{\mathrm{a}}$ \\
\hline 35 & $8.5^{\mathrm{d}}$ & $11 \mathrm{c}$ & $13.5 \mathrm{a}$ & $13.2 \mathrm{ab}$ & $11.5 \mathrm{bc}$ & $14.7^{\mathrm{a}}$ \\
\hline \multirow[t]{2}{*}{48} & $11.5^{\mathrm{b}}$ & $12.2 \mathrm{~b}$ & $13.5 \mathrm{ab}$ & $13.7 \mathrm{ab}$ & $13.7 \mathrm{ab}$ & $15.2^{\mathrm{a}}$ \\
\hline & \multicolumn{6}{|c|}{ Root length (cm) } \\
\hline 21 & $9.7^{\mathrm{b}}$ & $10.1^{\mathrm{b}}$ & $15.0^{\mathrm{a}}$ & $14.0^{\mathrm{ab}}$ & $11.7^{\mathrm{ab}}$ & $13.5^{\mathrm{ab}}$ \\
\hline 35 & $15.7^{\mathrm{b}}$ & $18.2^{\mathrm{ab}}$ & $22.0^{\mathrm{a}}$ & $20.2^{\mathrm{ab}}$ & $18.2^{\mathrm{ab}}$ & $22.2^{\mathrm{a}}$ \\
\hline 48 & $16.5^{\mathrm{c}}$ & $24.2^{\mathrm{ab}}$ & $27.0^{\mathrm{a}}$ & $22.2^{\mathrm{b}}$ & $21.2^{\mathrm{b}}$ & $24.2^{\mathrm{ab}}$ \\
\hline
\end{tabular}

Means followed by the same letter were not significantly different at $p<0.05$, Tukey's test. $\mathrm{ns}=$ not significant. Control, without fertilizer; Humic acids (HA); HA+NPK; NPK; Fulvic acids (FA); FA+NPK.

Table 3. Macro- and micronutrient contents of aerial dry mass in lettuce plants, obtained with the six experimental treatments at 48 DAT. Porto Alegre, UFRGS, 2013.

\begin{tabular}{|c|c|c|c|c|c|c|c|c|c|c|c|}
\hline \multirow{2}{*}{ Treatments } & $\mathbf{N}$ & $\mathbf{P}$ & $\mathbf{K}$ & $\mathrm{Ca}$ & Mg & $\mathbf{S}$ & $\mathrm{Cu}$ & Zn & Mn & $\mathrm{Fe}$ & B \\
\hline & \multicolumn{5}{|c|}{$\left(\mathrm{g} \mathrm{kg}^{-1}\right)$} & \multicolumn{6}{|c|}{$\left(\mathrm{mg} \mathrm{kg}^{-1}\right)$} \\
\hline Control & $19.2^{\mathrm{ns}}$ & $2.8^{\mathrm{ns}}$ & $19.8^{b}$ & $9.1^{\text {ns }}$ & $4.2^{\mathrm{ab}}$ & $2.3^{\mathrm{a}}$ & $5.2^{\mathrm{ab}}$ & $35.5^{\mathrm{ns}}$ & $113.2^{\mathrm{c}}$ & $208.2^{\mathrm{c}}$ & $34.1^{\mathrm{ns}}$ \\
\hline HA & $23.5^{\mathrm{ns}}$ & $3.4^{\mathrm{ns}}$ & $21.1^{\mathrm{b}}$ & $8.6^{\mathrm{ns}}$ & $5.5^{\mathrm{a}}$ & $2.3^{\mathrm{a}}$ & $7.4^{\mathrm{ab}}$ & $29.6^{\mathrm{ns}}$ & $116.5^{\mathrm{bc}}$ & $246.1^{\mathrm{c}}$ & $34.3^{\text {ns }}$ \\
\hline $\mathrm{HA}+\mathrm{NPK}$ & $17.4^{\mathrm{ns}}$ & $3.5^{\mathrm{ns}}$ & $27.0^{\mathrm{ab}}$ & $8.5^{\text {ns }}$ & $3.4^{\mathrm{b}}$ & $1.8^{\mathrm{b}}$ & $4.2^{\mathrm{b}}$ & $39.5^{\mathrm{ns}}$ & $183.5^{\mathrm{a}}$ & $671.4^{\mathrm{a}}$ & $32.4^{\mathrm{ns}}$ \\
\hline NPK & $19.6^{\mathrm{ns}}$ & $3.2^{\mathrm{ns}}$ & $22.4^{\mathrm{b}}$ & $8.2^{\mathrm{ns}}$ & $3.2^{\mathrm{b}}$ & $2.6^{\mathrm{a}}$ & $4.6^{\mathrm{b}}$ & $30.2^{\mathrm{ns}}$ & $139.5^{\mathrm{abc}}$ & $329.3^{\mathrm{bc}}$ & $32.1^{\text {ns }}$ \\
\hline FA & $21.1^{\mathrm{ns}}$ & $3.4^{\mathrm{ns}}$ & $26.1^{\mathrm{ab}}$ & $9.1^{\mathrm{ns}}$ & $5.4^{\mathrm{a}}$ & $2.4^{\mathrm{a}}$ & $7.1^{\mathrm{ab}}$ & $28.1^{\mathrm{ns}}$ & $182.2^{\mathrm{ab}}$ & $343.2^{\mathrm{bc}}$ & $33.3^{\mathrm{ns}}$ \\
\hline $\mathrm{FA}+\mathrm{NPK}$ & $17.1^{\mathrm{ns}}$ & $3.2^{\mathrm{ns}}$ & $35.4^{\mathrm{a}}$ & $10.5^{\text {ns }}$ & $4.3^{\mathrm{ab}}$ & $1.7^{\mathrm{b}}$ & $4.3^{\mathrm{b}}$ & $44.3^{\mathrm{ns}}$ & $198.3^{\mathrm{a}}$ & $566.5^{\mathrm{b}}$ & $34.2^{\mathrm{ns}}$ \\
\hline
\end{tabular}

Means followed by the same letter in each column were not significantly different at $p<0.05$, Tukey's test. ns $=$ not significant; Control, without fertilizer; Humic acids (HA); HA+NPK; NPK; Fulvic acids (FA); FA+NPK. 
nutrients in the lettuce leaves, only $\mathrm{K}$ content differed among treatments at the end of the experiment (Tables 3 and 4). Thus, FA+NPK treatment led to a $\mathrm{K}$ content of $35 \mathrm{~g} \mathrm{~kg}^{-1}$ that was significantly higher than the values for NPK, HA and Control treatments.
Baldotto et al. (2009) previously found out that HS application was increasing $\mathrm{K}$ contents in pineapple leaf dry mass by $50 \%$. As far as micronutrients concentrations are concerned, only $\mathrm{Fe}$ in combined treatments differed from the NPK treatment (Table 4).
Thus, HA+NPK almost doubled the Fe content obtained with NPK, while $\mathrm{FA}+\mathrm{NPK}$ increased 1.7 times the Fe concentration in ADM. These results suggest that FA boosted $\mathrm{K}$ uptake from the inorganic fertilizer, while both HA and FA stimulated Fe uptake. The

Table 4. Accumulated concentration of macro- and micronutrient in aerial dry mass in lettuce plants as obtained with the six experimental treatments at 48 DAT. Porto Alegre, UFRGS, 2013.

\begin{tabular}{lccccccccccc}
\hline \multirow{2}{*}{ Treatments } & $\mathbf{N}$ & $\mathbf{P}$ & $\mathbf{K}$ & $\mathbf{C a}$ & $\mathbf{M g}$ & $\mathbf{S}$ & $\mathbf{C u}$ & $\mathbf{Z n}$ & $\mathbf{F e}$ & $\mathbf{M n}$ & $\mathbf{B}$ \\
\cline { 2 - 12 } & & & \multicolumn{8}{c}{$\left.\mathbf{( m g ~ p l a n t ~}^{-1}\right)$} \\
Control & $121.1 \mathrm{~b}$ & $15.0 \mathrm{~d}$ & $116.4 \mathrm{c}$ & $59.7 \mathrm{~d}$ & $29.6 \mathrm{c}$ & $13.6 \mathrm{c}$ & $0.03 \mathrm{~b}$ & $0.22 \mathrm{~ns}$ & $1.29 \mathrm{~b}$ & $0.70 \mathrm{~d}$ & $0.21 \mathrm{e}$ \\
HA & $177.3 \mathrm{a}$ & $22.8 \mathrm{~cd}$ & $158.4 \mathrm{c}$ & $66.9 \mathrm{~cd}$ & $38.7 \mathrm{bc}$ & $16.6 \mathrm{bc}$ & $0.05 \mathrm{ab}$ & $0.22 \mathrm{~ns}$ & $1.86 \mathrm{~b}$ & $0.88 \mathrm{~cd}$ & $0.26 \mathrm{de}$ \\
HA+NPK & $189.9 \mathrm{a}$ & $33.5 \mathrm{ab}$ & $302.2 \mathrm{~b}$ & $89.8 \mathrm{~b}$ & $41.7 \mathrm{ab}$ & $16.7 \mathrm{abc}$ & $0.05 \mathrm{ab}$ & $0.43 \mathrm{~ns}$ & $7.37 \mathrm{a}$ & $2.01 \mathrm{ab}$ & $0.35 \mathrm{ab}$ \\
NPK & $187.8 \mathrm{a}$ & $31.4 \mathrm{abc}$ & $214.6 \mathrm{bc}$ & $82.4 \mathrm{bc}$ & $38.7 \mathrm{bc}$ & $20.2 \mathrm{a}$ & $0.06 \mathrm{a}$ & $0.29 \mathrm{~ns}$ & $3.21 \mathrm{~b}$ & $1.36 \mathrm{bcd}$ & $0.33 \mathrm{bc}$ \\
FA & $176.4 \mathrm{a}$ & $25.6 \mathrm{bc}$ & $213.4 \mathrm{bc}$ & $78.3 \mathrm{bcd}$ & $41.6 \mathrm{ab}$ & $19.2 \mathrm{ab}$ & $0.06 \mathrm{a}$ & $0.23 \mathrm{~ns}$ & $2.82 \mathrm{~b}$ & $1.50 \mathrm{bc}$ & $0.28 \mathrm{bc}$ \\
FA+NPK & $201.1 \mathrm{a}$ & $39.5 \mathrm{a}$ & $415.8 \mathrm{a}$ & $120.5 \mathrm{a}$ & $49.6 \mathrm{a}$ & $19.3 \mathrm{ab}$ & $0.05 \mathrm{ab}$ & $0.52 \mathrm{~ns}$ & $6.73 \mathrm{a}$ & $2.36^{\mathrm{a}}$ & $0.38 \mathrm{a}$ \\
\hline
\end{tabular}

Means followed by the same letter in each column were not significantly different at $\mathrm{p}<0.05$, Tukey's test. ns $=$ not significant; Control, without fertilizer; Humic acids (HA); HA+NPK; NPK; Fulvic acids (FA); FA+NPK.

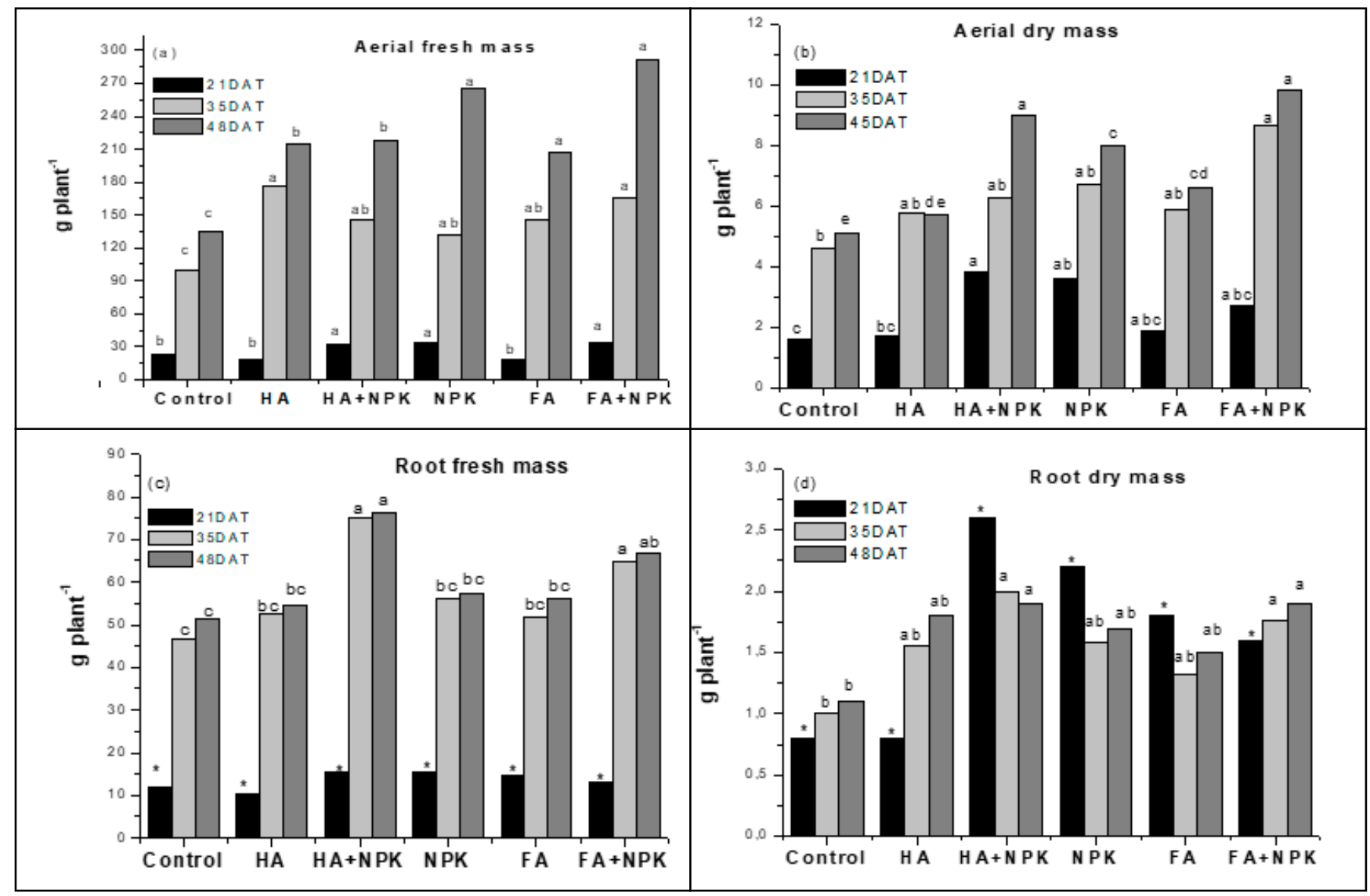

Figure 1. Aerial fresh mass (AFM) (a) and dry mas (ADM) (b); root fresh mass (RFM) (c) and dry mass (RDM) (d) in lettuce plants from six treatments at 21,35 and 48 DAT. Means followed by the same letter were not significantly different at $p<0.05$, Tukey's test. *not significant; DAT= days after transplanting. Control, without fertilizer; Humic acids (HA); HA+NPK; NPK; Fulvic acids (FA); FA+NPK. Porto Alegre, UFRGS, 2013. 
formation of Fe-humic substances complexes probably promoted $\mathrm{Fe}$ availability in soil, increasing its absorption and facilitating its movement and translocation into plants (Zanin et al., 2019).

The FA-rich biostimulant possibly increased $\mathrm{K}$ uptake by activation of $\mathrm{H}^{+}$-ATPases that, in turn, increased the electrochemical proton gradient and thus enhancing ion transport across cell membranes via secondary routes (Baldotto et al., 2009; Canellas et al., 2015). In relation to $\mathrm{Fe}$, its increased affinity for large humic micelles (i.e. HA) relative to small humic micelles (i.e. FA) (Santana et al., 2011) may have facilitated its chelation and hence increased its availability for absorption by roots with the HA+NPK treatment.

In this work, HS-based biostimulants were found to perform on par with mineral fertilizer in relation to lettuce production on an agricultural Ultisol. The preliminary results reported in this study indicate that the application of FA and/or HA has a significant biostimulant effect on several examined variables: plant height, number of leaves, diameter, and root length.

The joint use of a FA-rich biostimulant and inorganic fertilizer increased the lettuce productivity relative to the inorganic fertilizer alone. This effect may have arisen from the small micelle size of FA relative to $\mathrm{HA}$, thus triggering $\mathrm{H}+$-ATPases to a greater extent, but this hypothesis requires testing. The application of FA-rich biostimulant combined with NPK fertilizer also influenced $\mathrm{K}$ and Fe uptake by the plants and also, their accumulation in the aerial portion. In the presence of NPK, the FA-rich biostimulant boosted $\mathrm{K}$ uptake and the HA-rich biostimulant Fe uptake. Our study demonstrated that soil application of FA and HA is a promising strategy to promote plant growth and increase marketable yield of lettuce.

The use of FA and $\mathrm{HA}$ as biostimulant represents a cost-effective and environmental-friendly tool to improve nutrient uptake by promoting sustainable agricultural practices. However, to confirm the applicability of HS-based biostimulant for lettuce production, field studies should be carried out.

\section{ACKNOWLEDGEMENTS}

This research was funded by the Brazilian Council for Scientific and Technological Development (CNPq) by granting scholarship to Ana Cristina Lüdtke (M.Sc.), Deborah Pinheiro Dick (Researcher) and Luiza Morosino and Vicente Kraemer (undergraduate). The authors thank NUTRICELER-Soluções Nutricionais (Itapeva, São Paulo) for supplying samples of HS-based biostimulant Growmate Soil ${ }^{\mathrm{TM}}$ and Growmate Plant ${ }^{\mathrm{TM}}$.

\section{REFERENCES}

BALDOTTO, LEB; BALDOTTO, MA; CANELLAS, LP; SMITH, RB; OLIVARES, FL. 2010. Growth promotion of pineapple 'Vitória' by humic acids and Burkholderia spp. during acclimatization. Revista Brasileira de Ciência do Solo 34: 1593-1600.

BALDOTTO, LEB; BALDOTTO, MA; GIRO, VB; CANELLAS, LP; SMITH, RB; OLIVARES, FL. 2009. Desempenho do abacaxizeiro 'Vitória' em resposta à aplicação de ácidos húmicos durante a aclimatação. Revista Brasileira de Ciência do Solo 33: 979-990.

BALDOTTO, MA, BALDOTTO, LEB. 2016. Initial performance of corn in response to treatment of seeds with humic acids isolated from bokashi. Revista Ceres 63: 62-67.

BALDOTTO, MA; SOUZA, AC; VIANA, MCM; ALMEIDA, DD; BALDOTTO, LEB. 2017. Bioatividade das substâncias húmicas extraídas de solos manejados com integração, lavoura, pecuária e floresta. Revista Ceres 64: 540-547.

BRAZILIAN HORTI \& FRUTI YEARBOOK. 2019. KIS, BB; SANTOS, CE; CARVALHO, C; BELING, RR (eds). Santa Cruz do Sul: Editora Gazeta Santa Cruz, 96p. Available at: http://www.abcsem.com.br/upload/arquivos/ HortiFruti_2019_DUPLA.pdf. Accessed March 30, 2020.

CALVO, P; NELSON, L; KLOEPPER, JW. 2014. Agricultural uses of plant biostimulants. Plant and Soil 383: 3-41.

CANELLAS, LP; OLIVARES, FL; AGUIAR, NO; JONES, DL; NEBBIOSO, A; MAZZEI, P; PICCOLO, A. 2015. Humic and fulvic acids as biostimulants in horticulture. Scientia Horticulturae 196: 15-27.

COMISSÃO DE QUÍMICA E FERTILIDADE DO SOLO - CQFS-RS/SC. 2016. Manual de calagem e adubação para os Estados de Rio Grande do Sul e de Santa Catarina. 11.ed. Porto Alegre: SBCS, Núcleo Regional Sul.
DENRE, M; SOUMYA, GH; KHEYALI, SH. 2014. Effect of humic acid application on accumulation of mineral nutrition and pungency in garlic (Allium sativum L.) International Journal of Biotechnology and Molecular Biology Research 5: 7-12.

FAO. FOOD AND AGRICULTURE ORGANIZATION. 2017. Date of lettuce y chicoria. FAOESTAD (en linea) available at: http://www.fao.org/faostat/es/\#data/QC. Accessed April 02, 2020.

FERREIRA, DF. 2011. Sisvar: a computer statistical analysis system Ciência e Agrotecnologia 35: 1039-1042.

GARCÍA, AC; TAVARES, OCH; BALMORI, DM; SANTOS, VA; CANELLAS, LP; GARCIA-MINA, JM; BERBARA, RLL. 2018. Structure-function relationship of vermicompost humic fractions for use in agriculture. Journal of Soils and Sediments 18: 1365-1375.

GENG, J; YANG, X; HUO, X; CHEN, J; LEI, S; LI, H; LANG, Y; LIU, Q. 2020. Effects of controlled-release urea combined with fulvic acid on soil inorganic nitrogen, leaf senescence and yield of cotton. Scientific Reports 10: 17135.

GROWMATE International LCC. 2020. Soil. Available at: <http://growmateintl.com/ products/agriculture/growmate-soil/>. Accessed June 28, 2020.

HORTIBRASIL. 2019. Programa brasileiro para a modernização da horticultura. Available at: http://www.hortibrasil.org.br/ classificacao/ alface/alface.html. Accessed April 19, 2019.

JARDIN, P. 2015. Plant biostimulants: definition, concept, main categories and regulation. Scientia Horticulturae 196: 3-14.

JESUS, AA; LIMA, SF; VENDRUSCOLO, EP; ALVAREZ, RCF; CONTARDI, LM. 2016. Análise econômica da produção do milho doce cultivado com aplicação de bioestimulante via semente. Revista de La Facultad de Agronomía 115: 119-127.

KAZEMI, M. 2013. Effect of foliar application of humic acid and potassium nitrate on cucumber growth. Bulletin of Environmental Pharmacology and Life Sciences 2: 3-6.

NARDI, S; SCHIAVON, M; FRANCIOSO, O. 2021. Chemical structure and biological activity of humic substances define their role as plant growth promoters. Molecules 26: 2256.

PICCOLO, A. 2016. In memorian prof. FJ Stevenson and the question of humic substances in soil. Chemical and Biological Technologies in Agriculture 3: 23.

RODRIGUES, LU; SILVA, RR; FREITAS, GA; SANTOS, ACM; TAVARES, RC. 2018. Ácidos húmicos no desenvolvimento inicial de alface. Pesquisa Aplicada \& Agrotecnologia 11: 101-109.

SANTANA, GS; DICK, DP; JACQUES, AVA; CHITARRA, GS. 2011. Substâncias húmicas e suas interações com $\mathrm{Fe}$ e $\mathrm{Al}$ em Latossolo subtropical sob diferentes sistemas de manejo de pastagem. Revista Brasileira de Ciência do Solo 35: 461-472.

SOOTAHAR, M; ZENG, X; SU, S; WANG, Y; BAI, L; ZHANG,Y; LI, T, ZHANG X. 2019. 
The effect of fulvic acids derived from different materials on changing properties of Albic black soil in the Northeast plain of China. Molecules 18: 1535.

SUH, HY; YOO, KS; SUH, SG. 2014a. Tuber growth and quality of potato (Solanum tuberosum L.) as affected by foliar or soil application of fulvic and humic acids. Horticulture, Environment, and Biotechnology 55: 183-189.

SUH, HY; YOO, KS; SUH, SG. 2014b. Effect of foliar application of fulvic acid on plant growth and fruit quality of tomato (Lycopersicon esculentum L.). Horticulture Environment Biotechnology 55: 455-461.

TEDESCO, MJ; GIANELLO, C; BISSANI, CA; BOHNEN, H; VOLKWEISS, SJ. 1995. Análise de solo, plantas e outros materiais. Porto Alegre: UFRGS. 174p.

TURAN, ME; EKINCI, M; ARGIN, S. 2021. Effect of biostimulants on yield and quality of cherry tomatoes grown in fertile and stressed soils. HortScience 56: 414-423.

WU, A. 2018. Hot bio-stimulants gain traction in Latin American market. Available at: http://news.agropages.com/News/ NewsDetail---19117.htm. Accessed September 7, 2020.

ZANDONADI, DB; SANTOS, MP; BUSATO, J; PERES, L; FAÇANHA, AR. 2014. Plant physiology as affected by humified organic matter. Theoretical and Experimental Plant Physiology 25: 12-25.

ZANIN, L; TOMASI, N; CESCO, S; VARANINI, Z; PINTON, R. 2019. Humic substances contribute to plant iron nutrition acting as chelators and biostimulants. Frontiers in Plant Science 10: 675. 